\title{
Management of Chronic Non-Healing Wound using Ayurvedic drugs - A Case Study
}

\author{
Case Report
}

\section{Hemanta Kumar Panigrahi ${ }^{*}$}

1. Research officer (Ay.) Scientist-3, Central Ayurveda Research Institute for Cardiovascular disease, Punjabi Bagh, New Delhi,(CCRAS) Ministry of AYUSH, Govt. of India

\begin{abstract}
Sushruta in $1^{\text {st }}$ part of his compendium described about wound healing its types etc. as Vranitopasaniya adhyaya. Ayurveda described so many compound medicines and oil for oral administration and topical application to accelerate the wound healing. But this is not scientifically validated. So there is always a search for finding a newer and better medicine for wound healing. I am presenting a case of 42 year old married male with complain of superficial external wound with mild pain, mal odour and not healing since 45 days in spite of taking allopathic conventional treatment in his lower limb. The study was done in my outpatient department of Central Research institute for cardiovascular disease, Punjabi Bagh, New Delhi. On examination it was found that surface area of superficial wound is $22.5 \mathrm{sq}$. cm. having full thickness, skin loss involving necrosis of subcutaneous tissue extended down to underlying fascia. Necessary laboratory investigations were done prior to initiate the treatment. The wound was irrigated with Panchvalkala kasaya and dressing with Jatyadi Tail was done daily followed by oral intake of Triphala guggulu 500mg twice in a day and Amalaki churna $6 \mathrm{gm}$ twice in a day was administered orally for 28th days. Periodic follow up was done on $0,7,14$, and in 28 days. This regimen was found to be effective in faster wound epithelialization, and reducing wound exudates. There was no evidence of any allergic reaction as well as no evidence showing any adverse event on the wound.
\end{abstract}

Key Words: Jirna vrana, Non-healing wound, Re-epithelialisation, Irrigation.

\section{Introduction}

A chronic wound may be defined as one that is physiologically impaired due to a disruption of the wound healing cycle as a result of impaired angiogenesis, innervation, or cellular migration (1). The time taken for complete epithelialization differs depending on various factors, morbidities (e.g., diabetes, autoimmune disease and peripheral artery disease), increased body mass index, anatomic location, and medications.

On the basis of time required to heal the wound we can't differentiate chronic wound from acute wound. Some suggest that lack of 50 percent reduction of the surface area of wound in one month time is regarded as chronic wound (2). The chronic, non-healing wound is prone to infection, and causes pain, diminished quality of life (3). Ayurveda is an ancient science. Topical applications of Ayurveda medicated oil and oral administration of compound Ayurveda medicine for accelerated wound healing have been practiced

\section{* Corresponding Author:}

\section{Hemanta Kumar Panigrahi}

Research officer (Ay.) Scientist-3, Central Ayurveda

Research Institute for Cardiovascular disease,

Punjabi Bagh, New Delhi,(CCRAS)

Ministry of AYUSH, Govt. of India.

Email Id: drhemanta71@gmail.com historically. Different wounds require dressings for different reasons. Some wounds need protection from exogenous infection while others need a conducive environment for healing till the skin regenerates. Accelerated re-epithelialization, minimizing pain and preventing infection are main goals of dressing care. Conventional paraffin gauze dressings are inexpensive but do not contain any active agent that can promote wound healing. Thus, the quest for finding newer and better alternatives is a continuous endeavour in medical research.

\section{Case report}

A 42 year old married male with complain of superficial external wound having mild pain, mild mal odour and not healing in the lower limb since 28th day in spite of taking allopathic conventional treatment was attended in my outpatient Department at Central Ayurveda Institute for Cardiovascular disease, Punjabi Bag, New Delhi. On examination it was found that surface area of superficial wound is $22.5 \mathrm{sq} . \mathrm{cm}$. having full thickness skin loss involving necrosis of subcutaneous tissue extended down to underlying fascia. The wound was caused by road traffic accident. His vitals like pulse rate, blood pressure, respiration rate were normal. Besides, systemic examination was done and no significant morbidities are found. He was from a medium socioeconomic background. The patient was a non-smoker and a non-alcoholic. There was no significant history of illness and family history except 
Hemanta Kumar Panigrahi et.al., Management of chronic non-healing wound using Ayurvedic drugs - A case study

the patient's father was a smoker and use to take 'bidi'. After taking these details, the present history of the illness, past history and family history of the patient was taken. Laboratory investigations like TLC, DC, ESR, KFT, LFT, Blood Sugar Fasting and Post Prandial was done at base line and after 28 days of the study. On the basis of his history and laboratory investigations it was diagnosed as Jirna vrana (Chronic non healing wound). The Bates Jensen wound assessment tool was used periodically to assess the result.

\section{Procedure and drug intervention}

Under aseptic condition the wound was irrigated with Panchavalkala kahsaya. The wound site was treated with sufficient quantity of sterile Jatyadi Taila. Then the site was normally dressed with nonadherent primary dressings. Concomitant systemic medication like Triphala guggulu 500mg twice daily after food and Amalaki churna 6gm twice daily with plain water was given orally for 28 days. In Follow ups wound evaluation were done on Baseline, 7th, 14th and $28^{\text {th }}$ day.

\section{Total duration of treatment 28days}

\section{Procurement of drugs}

All the drugs were procured from IMPCL, which supplies to our Hospital

\section{Table No: 1: Medications}

\begin{tabular}{|l|l|l|l|}
\hline $\begin{array}{l}\text { Sl } \\
\text { No }\end{array}$ & $\begin{array}{l}\text { Name of the } \\
\text { Drugs }\end{array}$ & $\begin{array}{l}\text { Dose and } \\
\text { duration }\end{array}$ & Anupana \\
\hline $\mathbf{1}$ & Triphala gugulu & $\begin{array}{l}\text { 500mg twice } \\
\text { in a day for } 28 \\
\text { days }\end{array}$ & $\begin{array}{l}\text { Normal } \\
\text { water After } \\
\text { food }\end{array}$ \\
\hline $\mathbf{2}$ & Amalaki Churna & $\begin{array}{l}\text { 6gm twice in a } \\
\text { day for } 28\end{array}$ & $\begin{array}{l}\text { With } \\
\text { normal } \\
\text { days }\end{array}$ \\
\hline $\mathbf{3}$ & Jatyadi Tail & $\begin{array}{l}\text { Quantity } \\
\text { sufficient }\end{array}$ & $\begin{array}{l}\text { For local; } \\
\text { application. }\end{array}$ \\
\hline $\mathbf{4}$ & $\begin{array}{l}\text { Panchavalkala } \\
\text { Kashaya }\end{array}$ & $\begin{array}{l}\text { Quantity } \\
\text { sufficient }\end{array}$ & $\begin{array}{l}\text { For wound } \\
\text { irrigation }\end{array}$ \\
\hline
\end{tabular}

\section{Assessment}

\section{Assessment tool}

In this case study I have used Bates Jensen wound assessment tool (4) for wound evaluation, on the basis of 13 criteria. Score of each category was taken and used for analysis.

\section{Wound Assessment criteria: Bates-Jensen wound assessment tool \\ 1. Size}

1-Length $\mathrm{x}$ width $<4 \mathrm{sq} \mathrm{cm}$

2 - Length $x$ width $4<16 \mathrm{sq} \mathrm{cm}$

3-Length $x$ width $16.1<36 \mathrm{sq} \mathrm{cm}$

4- Length $x$ width $36.1<80$ sq. $\mathrm{cm}$

5-Length $\mathrm{x}$ width $>80$ sq. $\mathrm{cm}$
2. Depth

1-Non-blanchable erythema on intact skin

2-Partial thickness skin loss involving epidermis \&/ or dermis

3-Full thickness skin loss involving damage or necrosis of subcutaneous tissue; may extend down to but not through underlying fascia; \&/or mixed partial \& full thickness \&/or tissue layers obscured by granulation tissue

4-Obscured by necrosis

5-Full thickness skin loss with extensive destruction, tissue necrosis or damage to muscle, bone or supporting structures

3. Edges

1-Indistinct, diffuse, none clearly visible

2-Distinct, outline clearly visible, attached, even with wound base

3-Well-defined, not attached to wound base

4-Well-defined, not attached to base, rolled under, thickened

5-Well-defined, fibrotic, scarred or hyperkeratotic

\section{Undermining}

1 - None present

2-Undermining $<2 \mathrm{~cm}$ in any area

3-Undermining $2-4 \mathrm{~cm}$ involving $<50 \%$ wound margins

4-Undermining $2-4 \mathrm{~cm}$ involving $>50 \%$ wound margins

5-Undermining $>4 \mathrm{~cm}$ or Tunnelling in any area

\section{Necrotic Tissue Type}

1 - None visible

2- White/grey non-viable tissue \&/or non-adherent yellow slough

3- Loosely adherent yellow slough

4- Adherent, soft, black eschar

5- Firmly adherent, hard, black eschar

6. Necrotic Tissue Amount

1 - None visible

$2-<25 \%$ of wound bed covered

$3-25 \%$ to $50 \%$ of wound covered

$4->50 \%$ and $<75 \%$ of wound covered

$5-75 \%$ to $100 \%$ of wound covered

7. Exudate Type

1-None

2-Bloody

3-Serosanguinous: thin, watery, pale red/pink

4-Serous: thin, watery, and clear

5-Purulent: thin or thick, opaque, tan/yellow, with or without odour

8. Exudate Amount

1- None, dry wound

2- Scant, wound moist but no observable exudate

3- Small

4-Moderate

5-Large

\section{Skin Colour Surrounding Wound}

1- Pink or normal for ethnic group

2-Bright red \&/or blanches to touch

3-White or grey pallor or hypo pigmented

4-Dark red or purple \&/or non-blanchable

5- Black or hyper pigmented 


\section{Tissue Edema}

1-No swelling or edema

2- Non-pitting edema extends $4 \mathrm{~cm}$ around wound

3 -Non-pitting edema extends $>4 \mathrm{~cm}$ around wound

4-Pitting edema extends $<4 \mathrm{~cm}$ around wound

5-Crepitus and/or pitting edema extends $>4 \mathrm{~cm}$ around wound

11. Peripheral Tissue Induration
1 - None present
2- Induration, $<2 \mathrm{~cm}$ around wound
3-Induration $2-4 \mathrm{~cm}$ extending $<50 \%$ around wound
4-Induration $2-4 \mathrm{~cm}$ extending $>50 \%$ around wound
5- Induration $>4 \mathrm{~cm}$ in any area around wound

\section{Granulation Tissue}

1-Skin intact or partial thickness wound

2- Bright, beefy red; $75 \%$ to $100 \%$ of wound filled \&/or tissue overgrowth

3 - Bright, beefy red; $<75 \% \&>25 \%$ of wound filled

4-Pink, \&/or dull, dusky red \&/or fills $<25 \%$ of wound

5- No granulation tissue present

13. Epithelialization

1- $100 \%$ wound covered, surface intact

$2-75 \%$ to $<100 \%$ wound covered \&/ or epithelial tissues extends to $>0.5 \mathrm{~cm}$ into wound bed

$3-50 \%$ to $<75 \%$ wound covered \&/ or epithelial tissues extends to $<0.5 \mathrm{~cm}$ into wound bed $4-25 \%$ to $<50 \%$ wound covered

$5-<25 \%$ wound covered

Table No: 2: Result

\begin{tabular}{|c|l|c|c|c|c|}
\hline SI No & Wound character & $\begin{array}{c}\text { Base line Score } \\
\text { At base line }\end{array}$ & $\begin{array}{c}\text { Score at } \\
\mathbf{7} \text { days }\end{array}$ & $\begin{array}{c}\text { Score at } \\
\mathbf{1 4} \text { days }\end{array}$ & $\begin{array}{c}\text { Score at } \\
\mathbf{2 8} \text { days }\end{array}$ \\
\hline 1 & Size & 3 & 3 & 2 & 1 \\
\hline 2 & Depth & 3 & 3 & 2 & 2 \\
\hline 3 & Edge & 2 & 2 & 2 & 1 \\
\hline 4 & Undermining & 1 & 1 & 1 & 1 \\
\hline 5 & Necrotic Tissue Type & 2 & 2 & 1 & 0 \\
\hline 6 & Necrotic Tissue Amount & 2 & 2 & 1 & 0 \\
\hline 7 & Exudate type & 4 & 3 & 1 & 0 \\
\hline 8 & Exudate Amount & 3 & 3 & 2 & 1 \\
\hline 9 & Skin Colour surrounding wound & 1 & 1 & 1 & 1 \\
\hline 10 & Peripheral tissue oedema & 1 & 1 & 1 & 0 \\
\hline 12 & Peripheral Tissue Induration & 1 & 1 & 1 & 0 \\
\hline 13 & Granulation Tissue & 4 & 4 & 2 & 1 \\
\hline 14 & Epithelization & 5 & 3 & 2 & 1 \\
\hline
\end{tabular}

Table No 3: Periodic follow up photographs

\section{Base line (Fig-1)}

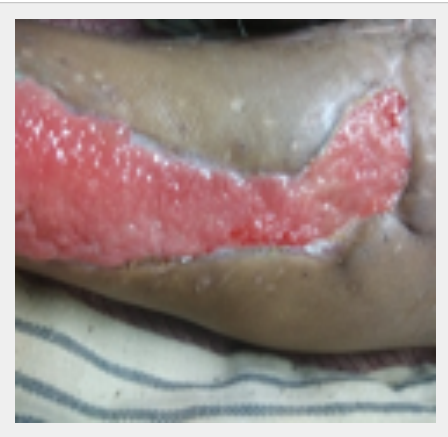

$7^{\text {th }}$ day

(Fig-2)

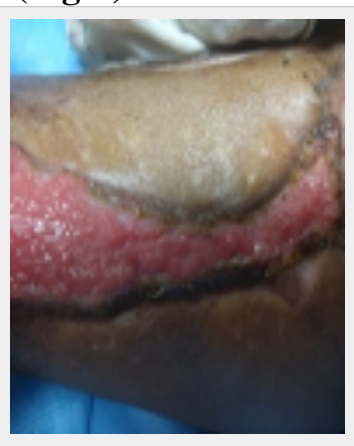

$1^{\text {th }} \operatorname{day}($ Fig-3)

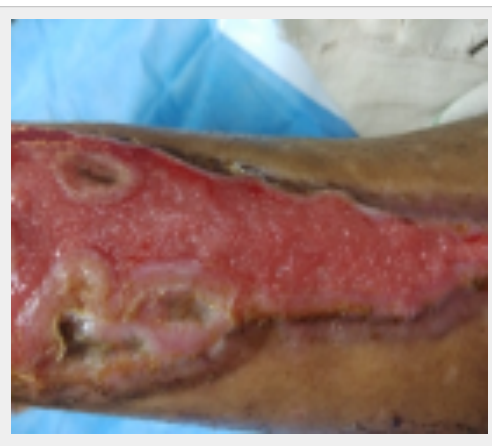

$2^{\text {th }}$ day(Fig-4)

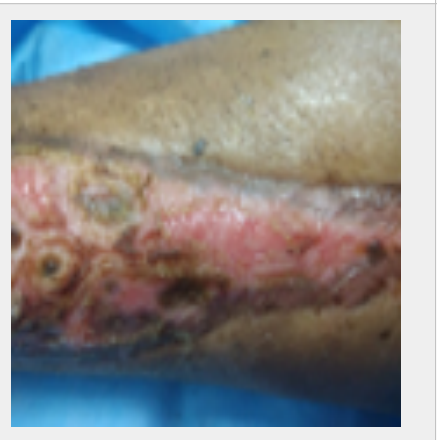

\section{Discussion}

Wound healing is a complex process have different phases, the inflammatory phase, the proliferative phase and the remodelling phase. Each phase has its unique contribution and specific steps as a whole to bring the process of wound healing. The basic principle is to minimize the damage to the tissues, provide nutrients, oxygen to the healing tissues and optimization of environment for rapid wound healing $(5,6)$. The problem in wound healing occur due to various factors local and systemic. Reactive oxygen species are one the important factors that hinders the process of wound healing (7). Free radical scavengers are protective against their reactive oxygen species. During the wound healing process the neutrophil cause respiratory burst which initiate the reactive oxygen species $(8)$. These are produced by other cells too by NADPH pathways (9). These species cause the lipid peroxidation, DNA damage and enzyme inactivation. Topical application of free radical scavenging compound reduces the oxidants burden and promote 
rapid wound healing (10) The wound size decreases when healing starts, this occurs in secondary wound healing due to contraction of myofibroblasts. In this case after application of Jatyadi Tail, the wound size decreased from score 3 to 1 (Table no.2) on day 7, 14

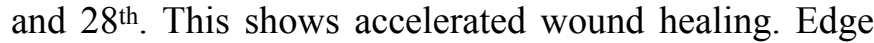
of the wound is an important feature; it gives a hint towards the aetiology. Healing wound have sloppy edges. Application of Jatyadi Tail along with Amalaki churna and Triphala Guggulu orally improved the wound edges on day 7 and day14. Exudate type and exudate amount depends upon the nature of wound. In chronic foul smelling wound the bio burden of wound is more hence exudate is more and also contains bacteria and other tissue metabolites. In this case on day7, day 14 and day 28 exudate type and exudate amount are decreased as shown in Table No 2.Triphala guggulu is an ayurvedic compound drug composed of purified Guggulu (Commiphora mukul). In Ayurvedic medicine anti allergic, antibacterial and blood purifying properties are found in this herbal preparation(11). Chief ingredients of Triphala gugulu is Triphala and Gugulu. Triphala has immunomodulatory, and Tridosha samak property and hence it reduces the oxidants burden and promote rapid wound healing. Amalaki (Emblica officinalis) powder contains heavy amounts of Vit $\mathrm{C}$. The major function of vitamin $\mathrm{C}$ (ascorbic acid) in wound healing is assisting in the formation of collagen, the most important protein of connective tissue (12) and also possess immune modulator activity that helps to heal the wound. Guggulu has anti-inflammatory effects which can decrease the tissue oedema of the peripheral skin around the wound. This may be due to active Phyto constituents, astringents and tannins (13). The drugs in Panchavalkala kashaya are Kashya Rasa, Sheeta Veerya, Katu Vipaka and kapha pittashamak. The malodour and discharge in wound are due to vitiated Kapha, and Pitta dosha. Panchavalkala is sheet veerya and Rukshya in nature and hence pacify the vitiated Pitta dosha and due to its Rukshya guna vitiated Kapha dosha pacified and hence reduces the malodour and discharges in wound. Besides it also contains antimicrobial substances. The Tannin founds in Panchavalkala Kashaya acts as Anti-inflammatory by inhibiting enzymes such as 5-lipoxygenase \& hyaluronidase. Tannins have been reported to have antibacterial activity (14). Jatyadi Tail contains Lodhra Neem, Haridra, Daruharidra, and Abhaya. These drugs are having antimicrobial activity. The ingredients like Manjistha, Sariva, and Karanja are vrunashodhaka (wound cleansing) properties. Katuka improves re-epithelialization, neo-vascularization and migration of endothelial cells, dermal fibroblasts into the wound bed (15). Jati is having vranaropaka (Wound healing) action. Tuttha induces vascular endothelial growth factor in the wound. Hence in Ayurveda Jatyadi taila is used as Shothahara, Vedanasthapaka and Vrana Ropaka (16)

\section{Conclusion}

Irrigation of Panchavalkala Kashaya followed

by Local application of Jatyadi Taila and oral administration of Triphala guggulu and Amalaki churna was found to be effective in faster wound epithelialization, and reducing wound exudates. There was no evidence of any allergic reaction as well as no evidence showing any adverse event on the wound. Hence this can be safely used in chronic non healing wound.

\section{Acknowledgement}

The author is very much thankful to the DG, CCRAS, New Delhi for technical support and also thankful to the study participant for his co-operation in completion of the study.

\section{References}

1. Golink, MS, Clark S, et.al,Wound emergencies: The importance of assessment, documentation and early treatment using a wound electronic medical record. Ostomy wound manage. April 2009:55:54

2. Sheehan P, et al. Percent change in wound area of Diabetic foot ulcer over a 4 week period is a robust predictor of complete healing in a 12 week prospective Trial. Plastic and Reconstructive Surgery, 2006.117:239S

3. Harding KG, Morris HL, Patel GK (2002) Science, medicine and the future: healing chronic wounds. BMJ 324(7330):160-163

4. Bates-Jensen B, Sussman C. Tools to measure wound healing. In Sussman C, Bates-Jensen B, editors. Wound Care, a Collaborative Practice Manual for Health Professionals, 4 ed. Baltimore (US): Lippincott Williams and Wilkins; 2012. p. 131-72

5. Bennett NT, Schultz GS. Growth factors and wound healing: biochemical properties of growth factors and their receptors. The American Journal of Surgery. 1993 Jun 1; 165(6):728-37.

6. Joseph E Grey, Stuart Enoch, research fellow, and Keith G Harding ABC of wound healing BMJ. 2006 Feb 4; 332(7536): 285-288.doi: 10.1136/ bmj.332.7536.285

7. Aliyev E, Sakallığlu U, Eren Z, Açıkgöz G. The effect of polylactide membranes on the levels of reactive oxygen species in periodontal flaps during wound healing. Biomaterials. 2004 Aug 1; 25(19):4633-37.

8. Babior BM. Oxygen-dependent microbial killing by phagocytes. New England Journal of Medicine. 1978 Mar 23; 298(12):659-668.

9. Griendling KK, Sorescu D, Ushio-Fukai M. NAD (P) $\mathrm{H}$ oxidase: role in cardiovascular biology and disease. Circulation research. 2000 Mar 17; 86(5):494-501.

10. Thiem B, Goślińska O. Antimicrobial activity of Rubus chamaemorus leaves. Fitoterapia. 2004 Jan 1; 75(1):93-5.

11. Nariyal, Vikas, Sherma, Omraj, Dhiman, KS. A combined efficacy of Kaishore guggulu and Punarnavadi guggulu in the management of vatarakta (Gout): A case series. Int.J.Adv.Res.5 (6). Page.1793-1794 
12. Ter Riet G, Kessels A G, \& Knipschild P G. (1995) Randomized clinical trial of ascorbic acid in the treatment of pressure ulcers. J Clin Epidemiol, 48(12), 1453-1460.

13. Ya C., Gaffney SH., Lilley TH., Haslam ELN RW., Karchesy JJ., Chemistry and significance of condensed tannins, Plenum: New York;1988:553.

14. Kavitha Sharma, Preeti Sharma, Swapnil Saini, Akhilesh K.Shrivastava. Study of Panchbalkal kashaya in Vaginal discharge W.S.R to
Antimicrobial Properties. International Journal of Ayurveda and Pharma Research. 2018; 6(4):52-57.

15. Samantaray, Sanghamitra, Bishwal,Radhakrishna, Singhai, Swapnil, Clinical efficacy of Jatyadi taila in Parikartika (fissure-in-ano wjpmr, 2017,3(8), 250-254

16. Shastri, Ambikadutta, Sushruta Samhita Chikitsa Sthana: Vol.I, Chaukahmbha Sanskrit Sansthan Varanasi publication, 2007; page no. 52. 